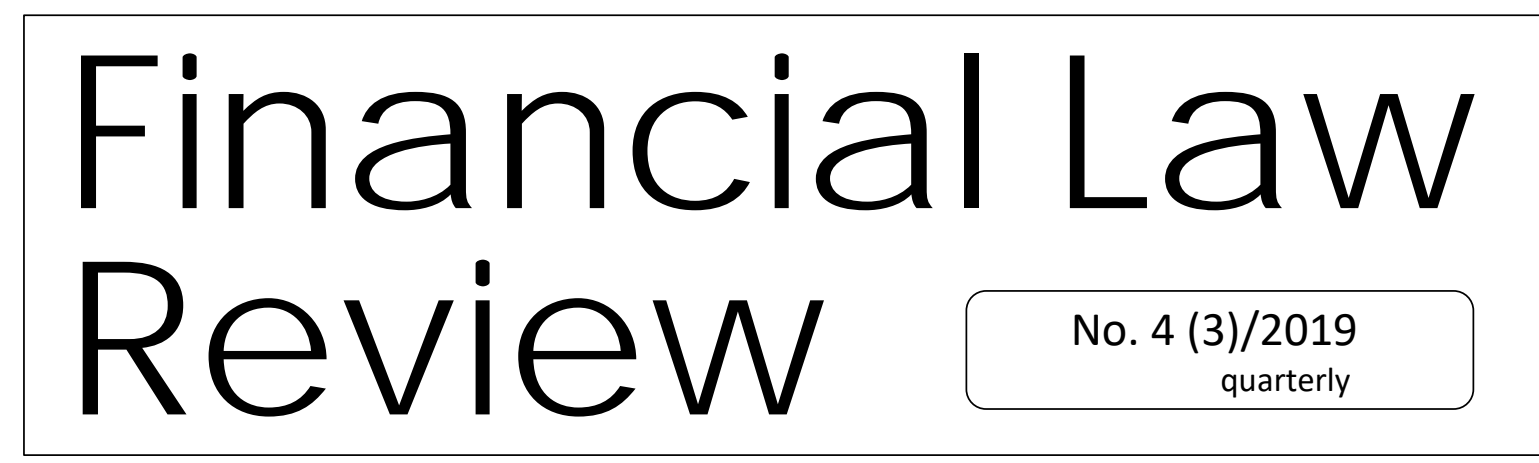

UNIVERSITY OF GDAŃSK • MASARYK UNIVERSITY • PAVEL JOZEF ŠAFÁRIK UNIVERSITY • UNIVERSITY OF VORONEZH http://www.ejoumals.eu/FLR

\title{
THE PRINCIPLE OF EFFICIENT PUBLIC SPENDING, AS PROCLAIMED BY THE PUBLIC FINANCE ACT SZYMON MOŚ *
}

\begin{abstract}
This contribution deals with the issue of the principle of efficient public spending, as pervading the Polish legal system. The aim of the paper is to decode and clarify the meaning of the notion of efficiency as part of the principle proclaimed by the Public Finance Act of 27 August, 2009. There exists no legal definition of the term and since the notion is not an independent one, a tendency towards intuitive understanding of the rule may arise. However, by applying a proper legal interpretation and referring to what other academic disciplines say, this article proves that the principle of efficient public spending has a specified, concrete and clear meaning, which should be taken into account in each and every case of public expenditure being borne under the Public Finance Act.
\end{abstract}

Key words: public finances, praxiology, efficiency, efficacy, principle of efficient spending JEL Classification: H500, K300

\footnotetext{
* Research assistant, Department of Financial Law, Faculty of Law and Administration, Gdańsk University, Poland; .
} 


\section{Introduction}

The notion of efficiency, as used in the realm of public finance, was introduced into the legal system by provisions of the Public Finance Act (hereinafter: PFA) establishing the principles for public spending. Efficiency, as a measure of performance (action) is, by the way, well-embedded in the recent history of the public finance sector [Skica 2010: 116]. The criterion of efficiency, and the rules of purposefulness, economy and promptness add up to form the directive of rational public spending [Gliniecka 2012: 93].

As pointed out in legal writings, Art. 44 para. 3 subpara. 1 item a PFA defines the criterion of efficiency by pointing out to its characteristics [Bitner 2015: 163]: achievement of the best results using specified resources. The provision does not, however, explain what the thus understood relation actually means. In normative terms, the "efficiency" standard is not an independent one (i.e. may not, for instance, be the only legal basis for liability under the Fiscal Discipline Act) but, the feature considered, constitutes a single structural element of legal standards when combined with other regulations [Bitner 2015: 163]. And thus, the attempt to decode its meaning usually involves resorting to a vague, general understanding of efficiency, other principles related thereto being quoted. At times, the notion of a result (effect) alone is separately made use of in addition [Kucia-Guściora 2012: 372-378], an analysis to explain the meaning of the efficiency principle as such not being actually undertaken.

The following paper aims at defining the way in which the efficiency principle, as provided for in PFA, is understood. Lacking in independent normative value, the rule does not lack in meaning, after all.

\section{The notion of efficiency and the ways in which it is approached}

\section{a. Efficiency, as viewed in praxiological terms}

In the light of praxiology, efficiency is a "positive feature of actions, the result of which is appraised as a success" [Pszczołowski 1978: 60]. It also can be characterised by the dynamics between goals, effects, outlays and costs [Skrzypek 2012: 313-314]. That statement considered, efficiency can be defined as a kind of a function of the results achieved and the resources employed [Brajer-Marczak 2012: 513]. Within that meaning an efficient action is one that brings the best result while being effective [Guziejewska 2008: 72], although - compared to the original praxiological concepts - the feature of effectiveness comes as secondary. It is derived from the discussion of the business (and also managerial) understanding of efficiency. 
Praxiology "in its pure form" does not identify an efficient action with the effective one - in its terms effectiveness exists as a factor (category) only where an intention occurs. Achieved through an efficient action can be an unintended result, in which case the action that has led to the result, when viewed against the intention is, actually, ineffective [Pszczołowski 1978: 60]. The action's efficiency is not affected by the same, though.

And yet the praxiological concept of efficiency has not turned out sufficient in all spheres of science (but also, and even more so, of practice - see eg. [Kostecki 1980: 53]) where the term can be encountered or for which it is of importance [Kowal 2013: 11] ${ }^{1}$. It was soon observed that the deficiency translated into the inability to make due comparative measurements and was leading to actions undertaken "by intuition" [Kostecki 1982: 19]. Consequently, the scope of the discussion on the notion was extended to include the fields of economic life and management, and the efficiency itself started to be viewed ${ }^{2}$ also through the lens of economics and managerial sciences.

\section{b. The economic approach to efficiency}

In economic terms, efficiency is strongly identified with the so-called Pareto efficiency. According to the latter, the criterion of an efficient action is a condition in which the standing of a specific entity cannot be improved without the position of another one being deteriorated [Stigliz 2004: 69]. That insight is closely linked to competitiveness, as far as free market competition is concerned in particular [Stigliz 2004: 73]. In the light of the Pareto concept, distortion of competitiveness leads to inefficiency [Begg 1993: 436-439]. That type of economic approach is applied, in the first turn, to the allocation of resources [Rutkowska 2013: 444].

Understood traditionally, economic efficiency is a certain computational (mathematic) magnitude [Skrzypek 2012: 316], defined using indicators ${ }^{3}$. As these are flawed in many a way, new efficiency measures are being permanently sought. The ensuing modifications of those contribute to a change in perspective towards the phenomenon they concern and, finally, result in the measures becoming obsolete or not being used ever more [Hawrylyshyn 1990: 247-256].

A different approach is needed as regards economic efficiency judged from the perspective of the operation of business entities. The essence of the thus perceived feature lies in the

\footnotetext{
1 As W. Kowal indicates, the development of a clear definition of efficiency in praxiology was an accomplishment of, first of all, the so-called Polish praxiological school.

${ }^{2}$ In an evolutionary way, as it was derived from purely praxiologial concepts.

${ }^{3}$ An even more detailed classification may be encountered, into the difference-based (the difference between outputs and inputs) and the indicative form (the quotient of outputs to inputs), e.g. [Melich 1980, 73-75].
} 
reasonable and thrifty way in which the operation of a specific entity is carried out, being based either on a "productivity formula, assuming the achievement of "maximum" effects at fixed (determined) inputs [or] on the rule of economy with predetermined effects sought at minimum level (volume) of the outlays sustained [Matwiejczuk 2000: 27]". Regardless of the operating option chosen, the efforts taken involve reduction of $\operatorname{costs}^{4}$, elimination of waste and increase in profitability [Skrzypek 2002: 188] varying, as appropriate, in terms of intensity.

Under such an approach efficiency can also be viewed as a measure based on the ratio of the results achieved to the resources used, assessed (estimated) ex ante and examined ex post [Jastrzębska 2016: 43-44]. This should be preceded by due analysis and economic calculus [Skrzypek 2012: 317]. Since it is the effects and costs that are subject to interpretation, the most precise outcome can be arrived at by applying that very notion of efficiency to the enterprise's operating activity [Kowal 2013: 20].

A resource-based notion of economic efficiency can also be distinguished, involving the criterion of goods distribution, and an approach that combines elements of strategy and organisation; this consists in a holistic view of the organisation and any and all factors influencing the latter's effectiveness [Skrzypek 2012: 316].

Since regardless of the way of economic approach to efficiency an ex ante analysis can be carried out, it is fully reasonable to take into account the aspect of effectiveness, overlooked by praxiology [Matwiejczuk 2000: 27]. In such case, the effectiveness, as an absolute value (not measured in specific units) „can be expressed by means of a dimensionless number denoting a ratio of two magnitudes: the expected and that achieved" [Zieleniewski 1975: 225]. The ineffectiveness under such conditions should be understood not only as a result missing the objective sought, but also as one that does not even facilitate achieving it ${ }^{5}$ [Zieleniewski 1975: 224].

\section{c. Efficiency in the light of managerial sciences}

The emergence, development and further evolution of managerial (organisational) approach to the notion of efficiency owes much to the refinement of the management theory [Ziębicki 2008: 236-242]. The latter has set out to abandon the sometimes adopted division into economic and non-economic efficiency [Pyszka 2015: 14], making reference to a set of concepts wider than that involving simply the notions employed by economics [Ziębicki 2008: 241].

\footnotetext{
${ }^{4}$ For an interesting discussion of costs in enterprises, as viewed from the perspective of Poland's emerging market econom, see also [Biliński 1993: 31-32].

${ }^{5}$ The author also indicates that effectiveness is inherently scalable, and that an action can be partly effective.
} 
The main reason for the set being so vast is, first of all, the dispute as to the theoretical essence of organisation as such. On the one hand, organisation is the subject of a kind of „designing” based upon certain model guidelines. On the other, it also is, when viewed separately, as "the organisation", exposed to influence by specific factors, internal and external alike [Bratnicki 1986: 33-34]. Hence the search for a measure of organisational efficiency quickly deviated from a one-dimensional look, to be replaced by multidimensional assessment [Kostecki 1980: 54-55] taking into account a plethora of factors (not forgetting even the issue of good - or bad - luck) [Bratnicki 2006: 19].

In the approach featured by the theory of organisation issues like output, productivity, profitability, effectiveness, performance, reasonableness have become subordinated to efficiency [Skrzypek 2012: 314], the latter being supposed to grow based on systemic ties between processes that make up management as a whole [Bielawa 2013: 34]. The growth should accompany the development of the organisation itself. Struggling with uncertainties of its environment, the organisation should adapt itself to the surrounding conditions and proceed on the path of self-development [Brajer-Marczak 2012: 514].

As regards efficiency perceived from the perspective of the management research, the linking of an efficient result with the objective pursued and its attainment also occurs at times. The variety of objectives that can be taken into account in that respect can be classified into: the official (core) objectives, the actual (strategic and functional) ones and those operational [Kowal 2013: 19] $]^{6}$. And yet, within the managerial approach to the issue of efficiency the component of purpose does not seem essential. The final result makes up just a single criterion of managerial efficiency assessment. The latter is conditional upon processes of both internal and external meaning, combined to form a coherent process of management [Lewin 1986: 517-518]. While internal processes are supposed to provide balance within the structure of the organisation, those external should secure the latter's due adjustment to determinants beyond its control [Ziębicki 2008: 239].

\section{Efficiency from the perspective of public finance}

\section{a. Efficiency and the essence of public finance}

The issue of public spending goes beyond the limits of the theory of financial law [Ostrowski 1970: 195] or - putting it more broadly - beyond the limits of jurisprudence in general ${ }^{7}$. It is thus well-justified to confront the results of a search for the conceptual scope

\footnotetext{
${ }^{6}$ This confirms the scope of managerial efficiency being broader than that economic, since economic efficiency is mostly about the above mentioned operating objectives, see also: [Rutkowska 2013: 441].

${ }^{7}$ When analysing the "interdisciplinary nature" it can be easily noticed that covered by financial law, as a branch of law in general, are matters from beyond the area of jurisprudence (concerning the field of economics, management and organisation theory or even political science).
} 
of efficiency conducted in praxiology or economics with what the legal standards, introducing the concept into the realm of law, provide.

Following the above outlined path aimed at explaining the concept of efficiency in the normatively understood area of public finance, a definition of the finance has to be provided first.

Viewed from the perspective of jurisprudence, public finance, in its most general meaning, consists in transfer of funds between entities through accumulation and distribution of financial resources by the State or a specific public law body ${ }^{8}$ in order to satisfy common needs [Jaśkiewiczowa 1968: 17-18], within the framework of the financial system [Ostrowski 1970: 14].

The definition, as coined by legal scholars, is supplemented by a legal definition (contained in Art. 3 PFA) proclaiming that the "public finance area comprises processes related to accumulation of public funds ${ }^{9}$ and distribution thereof". The processes are not specified in terms of their objectives (neither as far as a positive nor negative aspect is concerned). The description itself seems to attempt at putting a certain economic phenomenon into the framework of a legal definition [Frysztak 2015: 13-14]. While efforts to theoretically present the processes described in Art. 3 taking a purposive approach are sometimes undertaken [Mierzwa 2012: 64-65] ${ }^{10}$, they are, however, not derived directly from a legal standard and not always are they noticed [Frysztak 2015: 12-14].

And thus the analysis of the notion of public finance, as developed in legal terms, even if further extended in legal writings does not suffice to decode the meaning of efficiency under the provisions of PFA. Since, under the PFA, public finance has not been defined based on the aspect of purposefulness (or, alternatively, effectiveness), it is hard to judge which "model" of efficiency the statutory provisions contained in the Act can actually be reckoned towards. It is far insufficient to rely solely on the fact that the public finance may be characterised as a certain process, a phenomenon spread over time.

\footnotetext{
${ }^{8}$ Of an obvious importance in that respect is exercising the imperium, as entities from the public sphere do.

${ }^{9}$ Whether the public resources mentioned in Art. 3 PFA are identical with the "funds destined for public purposes", as provided for by Art. 216 para. 1 of the Constitution of the Republic of Poland remains a matter open to dispute in legal writing - see also e.g. [Chojna-Duch 2017: 66].

${ }^{10}$ The author points out to, inter alia, objectives resulting from functions of the State, those met, under longstanding financial forecasts, by units of local government or public tasks provided by regulations establishing the status of legal (central or local government) persons falling into the category of the public sector entities.
} 


\section{b. A systemic interpretation of the rule of efficient spending of public funds}

Considering the above said, when developing the notion of efficiency under provisions of the PFA, systemic interpretation of the earlier quoted Art. 44 para. 3 item 1 PFA should be carried out, as both the linguistic interpretation and that functional fail in that respect. The former is helpless against the non-existence of a relevant definition, the latter - due to the provision having, in itself, a non-normative nature, there being no functional guidelines that could be derived from the definition of public finance, either ${ }^{11}$.

The regulation in question provides that:

„3. The public spending should be made:

1) in a purposeful and thrifty way, following the rules of:

a) attainment of the best output from specific inputs;

b) optimum selection of methods and means to achieve the assumed goals".

Thus, in order to be efficient, each expenditure made from public funds should be, first of all, purpose-specific and made economically. According to the discussed provision, purposefulness and economy are inherently related to the expenditure supposed to be an efficient one. In the search for a PFA-wise notion of efficiency any of the two guidelines, proclaimed by the statute as the supreme ones, must thus not be overlooked or neglected. They are related to the efficiency viewed through the lens of economics, under the assessment of performance of enterprises taken in the way prompted by that very discipline [cf. item 2.3. above].

It is also the purposefulness stressed in the structure of the provision that speaks in favour of understanding the rule of efficiency in its economic, PFA-based meaning. This is because the purposefulness, completely ambivalent under the praxiological approach and not necessary as far as the managerial approach is concerned, is a criterion essential for the economic understanding of the rule of effectiveness.

The significance of such understanding results both from the link existing between the notion of objective with that of efficiency (essential, in particular, when making the said assessments ex ante) and from the analysis being carried out in the context of the results achieved (or contemplated to be met), i.e. completion of the objective attained against the resources used (planned to be applied). The criterion of the economy alone also subscribes to the approach. It is, in fact, the objective to reduce costs, liquidate the sources of waste

\footnotetext{
${ }^{11}$ The nature of the norm, identified in the course of the above discussion as a sort of a catch-all clause, applied in an "auxiliary” way each time when legal standards are being reconstructed under provisions of PFA, results in its varied functions, just as varied is the multitude of possible facts of life involved.
} 
and increase profitability, as already referred to when describing the "economic efficiency" 12 .

What is more, under Art. 44 para.3 item 1 PFA, referred to above, a purposeful and economical action must also involve optimum selection of means and methods applied. The optimum ${ }^{13}$ is a "set of values resulting in a variant most desirable for specific reasons, even with certain components having minimum values" [Pszczołowski 1978: 149]. Meanwhile, the optimisation itself means "the best possible solution to the task (...) stating the criteria that have to be met, the listed limitations considered " [Pszczołowski 1978: 149-150]. It should be noted that not in the case of all entities the components of a specific efficient status would have the maximum value, which makes the optimisation close to the Pareto efficiency. And the optimum, parallel to the efficiency in the Pareto meaning, will mean a solution most desirable, "the most appropriate" (given the assumptions).

Hence, as shown above, from the systemic point of view, the imperative that best effects should be achieved using specified inputs (as proclaimed by Art. 44 para. 3 subpara. 1 item a PFA) is, in a sense, contained within a terminological cluster that braces notions falling within the scope of economic efficiency (purposefulness, optimisation, economy). In fact, taking into account the obviously monetary nature of public finance [Jaśkiewiczowa 1968: 24-26], the efficiency rule established by PFA should be seen via the lens of economic efficiency ${ }^{14}$.

In the light of the foregoing considerations it can also be concluded that the directive to spend economically seems to point out more to the approach suitable for the assessment of business entity operation. Thus, rationality and thriftiness are the essential elements appropriate for the appraisal of efficiency of business entities. The Pareto efficiency, characteristic of the redistributive approach, can only be regarded as a supplementary criterion, given certain amount of its likeness to the imperative that the selected methods and means should be optimised (and ancillary towards it) ${ }^{15}$.

\footnotetext{
${ }^{12}$ Opinions are even voiced that stimulating economical management of resources is directly a component of efficiency - [Drwiłło 2005: 87].

${ }^{13}$ Optimus (Latin: the best, very good, most appropriate, deserving, beneficial); cf. [Korpanty 2005: 441].

${ }^{14}$ Which does not preclude shifting the discussion carried out under under the theory of efficiency onto other spheres of the state operation. An example can be the proposed assessment of efficiency of the state's political system (see e.g. [Zubik 2010: 420] - the author outwardly proposes mechanisms whereby a wellfunctioning state could make such an assessment. Similarly, the perspective of the operation of NGOs makes it necessary to recognise the non-financial dimensions of efficiency [Kafel 2009: 237-245].

${ }^{15}$ While opinions are sometimes voiced that the efficiency, as mentioned under PFA, also involves a search for solutions whereby the best social effect is ensured with the involvement of specified and limited financial outlays [cf. Kańduła 2005: 101-110], the expenditures recorded in the financial plan of a public finance sector entity have the nature of a limit that must not be exceeded (the Public Finance Act, Art. 52/1/2). It is thus the "absolute legal limit of expenditures" that is legally binding [Kucia-Guściora 2012: 399], and not an
} 
The said does not mean that the "economical formula" touched in the above discussion, as implied by provisions of Art. 44 para. 3 item 1 PFA, can be applied in the public sector on a "one-to-one" basis in each and every aspect thereof. Just the opposite, using it that way could pose serious difficulties [Gliniecka 2012: 93], since the public sphere is not, in principle, profit-oriented. Examining the efficiency of the sphere boils down mostly to analysing the costs sustained [Modzelewski 2009: 46] in order to achieve the tasks planned.

Hence the issue of cost efficiency in public spending should be reduced to the volume of the outlays made [Modzelewski 2009: 47]. In that "cost-oriented" approach to the economy-based formula the assumption is that specific outputs should be achieved while minimising the level of the expenditures made.

The conceptual scope of efficiency (as a component of the rule of efficient public spending), specified in such a way under provisions of FPA, should be applied in the event of each spending being made, whether it is a public finance sector entity or other unit that makes use or disposes of public resources ${ }^{16}$.

\section{Summary}

In short, it is necessary to stress that the Public Finance Act, when establishing the principle of public spending, states that: "The public spending should be made (...) following the rules of attainment of the best output from specific inputs".

While being a catch-all clause, the rule can, nevertheless, be filled with a specific content. Since there is no legal definition provided by the legislature, the linguistic interpretation cannot be applied. Given the absence of an explicit legal definition of public finance, the functional interpretation fails, either, as the rule is applied in an "auxiliary" way, varying from case to case. Thus, it is a systematic legal interpretation that is needed.

The directive (requirement) to spend public funds efficiently, stated in the wording of a relevant PFA standard, is preceded by a demand to make the spending in a purposeful and economical manner and is supplemented by the rule of optimum selection of methods and means aimed to attain the objectives assumed. Given the lack of legal definition, the instructions supposed to help decode the content of the rule of efficiency should be

instruction to make the expenditures (implement the plan) in full so as to maximise the effect. Even the activity-based budget assumes the expected results (see also: [Juchniewicz 2014: 327]) considering the expenditures (costs) planned, and the implementation of the tasks is measured against the adopted assumption - not a certain "unseen" and non-specified upper limit.

${ }^{16}$ Which follows directly from the Public Finance Act (Art. 4/1/2), providing for its ratione personae scope. While the content itself of Art. 4 is exposed to criticism (see e.g. [Mierzwa 2012: 80-89], it nevertheless builds up, rather indisputably, a mechanism whereby the application of the Act would "catch up" with the level of the public funds. 
analysed through making reference to other academic disciplines (similarly, by the way, as the efficiency principle itself).

Under the praxiological approach, efficiency is not linked to effectiveness. That approach is thus ruled out when undertaking a systemic interpretation of the rule of efficiency, since striving to achieve the assumed objectives is directly required by the PFA at making public spending.

The economic and managerial approach to efficiency must not be lost of sight, either. As far as the later is concerned, it is related to viewing the organisation as an entity, and the efficiency itself is judged in an multidimensional manner, with a whole range of issues that comprise the processes of management being subordinated to it. In particular, the problem of purpose is not an essential matter under the managerial approach. This creates an irremediable contradiction with the idea of purposeful spending, as provided for by the PFA. Analysing the managerial approach is thus of little use when discussing the principle of efficient public spending.

And, finally, there is the earlier mentioned economic approach to efficiency, which also needs consideration. Within that approach the PFA-stressed rule of optimum selection of methods and means aimed at attaining the contemplated objectives becomes similar to economic efficiency in the Pareto meaning.

Various ways of economic approach to efficiency can be spoken of, one of those particularly corresponding with the principle of efficiency proclaimed by the PFA. The said is the economic efficiency viewed from the perspective of operation of business entities. It involves the criteria of purposefulness (attainment of goals) and economy, which have to be observed in public spending as required by the PFA. In addition, that approach is also linked to reasonableness and thrift.

Bearing in mind that public expenditures should be made so as to attain the best outputs from specific inputs, a conclusion can be reached that the "economical formula" of efficiency, understood in terms of economics, is the correct one to decode the essence of the principle of efficient public spending under the PFA. Since operation of the public sphere is not profit-oriented, the formula should be understood and applied as a "costoriented" one - specific outputs are to be achieved while minimising the level of the expenditures borne.

Last but not least, the thus defined principle of efficient spending - the "cost-oriented" economical formula within the concept of economic efficiency - should be applied each and every time when public expenditures in terms of Public Finance Act are to be made. 


\section{References:}

Begg, D. et al.: Ekonomia [Economics], Warszawa: Państwowe Wydawnictwo Ekonomiczne [National Economic Press], 1993.

Bielawa, A.: Przegląd kryteriów i mierników efektywnościowych przedsiębiorstw nastawionych projakościowo [A Review of Efficiency Criteria and Measures at Quality-Focused Enterprises], Studia i Prace Wydziału Nauk Ekonomicznych i Zarządzania, Uniwersytet Szczeciński [Studies and works of the Faculty of Economics and Management, University of Szczecin, Poland], No. 34 (2013).

Biliński, W. et al.: Efektywność - nowe spojrzenie [Efficiency - A New Perspective], Przegląd Organizacji [Review of the Organisation] No. 10 (1993).

Bitner, M.: Art. 44 (in:) Misiąg, W. (ed.): Ustawa o finansach publicznych. Komentarz [The Public Finance Act. A Commentary], Warszawa: C.H. Beck, 2015.

Brajer-Marczak, R.: Efektywność organizacji z perspektywy modelu dojrzałości procesowej [Efficiency of Organisation from the Perspective of Process Maturity Model], Zarządzanie i Finanse [Governance and Finances] vol. 10, No. 1, part 3 (2012).

Bratnicki, M. et al.: Efektywność organizacji - istota i problemy [Efficiency of Organisation - The Essence and Issues], Doskonalenie Kadr Kierowniczych [Perfecting of Managerial Staff] No. 5[285] (1986).

Bratnicki, M. et al.: Efektywność organizacyjna i zarządzanie publiczne - wyłaniające się koncepcje, kluczowe wyzwania i kierunki dalszych badań w obszarze pomiaru efektywności [Organisational Efficiency and Public Management - the Emerging Concepts, Key Challenges and Directions of Further Research in the Area of Efficiency Measurement], Organizacja i Kierowanie [Organisation and Management] No. 3[125] (2006).

Chojna-Duch, E., Prawo finansowe. Finanse publiczne [Financial Law. Public Finance], Warszawa: Wiedza i Praktyka [Knowledge and Practice], 2017.

Drwiłło, A.: Kierunki racjonalizacji wydatków publicznych [Guidelines for Rationalisation of Public Spending] (in:) Głuchowski, J. et al.: Ekonomiczne i prawne problemy racjonalizacji wydatków publicznych [The Economic and Legal Issues of Public Spending Rationalisation], vol.. I, Lublin: Wydawnictwo Uniwersytetu Marii Skłodowskiej-Curie [The Marie-Curie Skłodowska University Press], 2005.

Frysztak, M.: Art. 3 (in:) Misiąg W. (ed.): Ustawa o finansach publicznych. Komentarz [The Public Finance Act. A Commentary], Warszawa: C.H. Beck, 2015.

Gliniecka, J.: Zasada racjonalnego wydatkowania środków publicznych [The Principle of Rational Public Spending], Gdańskie Studia Prawnicze [Gdańsk Legal Studies] 2012, vol. XXVII.

Guziejewska, B.: Efektywność finansów samorządu terytorialnego [The Efficiency of Local Government Finance], Gospodarka Narodowa [National Economy], No. 5-6 (2008).

Hawrylyshyn, B.: Drogi do przyszłości. Raport dla Klubu Rzymskiego [Roads Towards the Future. A Report for the Club of Rome], Warszawa: Polskie Towarzystwo Współpracy z Klubem Rzymskim [Polish Society of Cooperation with the Rome Club], 1990.

Jastrzębska, M.: Uwarunkowania pomiaru efektywności wydatków jednostek samorządu terytorialnego [The Determinants of Efficiency Measurement Concerning the 
Spending Made by Local Government Units], Finanse, Rynki Finansowe i Ubezpieczenia (Finances, Financial Markets and Insurances], nr 6[84] (2016).

Jaśkiewiczowa, J. et al.: Zarys nauki finansów publicznych [An Outline Theory of Public Finance], Warszawa: Państwowe Wydawnictwo Ekonomiczne [National Economic Press], 1968.

Juchniewicz, E.: Budżet zadaniowy [The Activity-Based Budget] (in:) Drwiłło, A. (ed.): Podstawy finansów i prawa finansowego [The Essentials of Public Finance and Financial Law], Warszawa: Wolters Kluwer, 2014.

Kańduła S.: Racjonalizacja wydatków budżetowych gmin z zakresu oświaty i wychowania [The Rationalisation of Spending on Education Made under Municipal Budgets] (in:) Głuchowski, J. et al: Ekonomiczne i prawne problemy racjonalizacji wydatków publicznych [Economic and Legal Issues of Public Spending Rationalisation], vol. II, Lublin: Wydawnictwo Uniwersytetu Marii Skłodowskiej-Curie [The Marie-Curie Skłodowska University Press], 2005.

Kafel, T. et al.: Wymiary i kryteria oceny efektywności organizacji pozarządowych [Dimensions and Criteria of NGO Efficiency Assessment] (in:) Nalepka, A. et al. (eds.): Organizacje komercyjne i niekomercyjne wobec wzmożonej konkurencji oraz wzrastających wymagań konsumentów [Commercial and Non-Commercial Organisations Faced by Increased Competition and Growing Consumer Requirements], Nowy Sącz: Wyższa Szkoła Biznesu - National-Louis University, 2009.

Korpanty, J. (ed.) Mały słownik łacińsko-polski [Little Latin-Polish Dictionary], Warszawa: PWN [National Scientific Press], 2005.

Kornberger-Sokołowska, E.: Art. 6 (in:) Misiąg, W. (ed.): Ustawa o finansach publicznych. Komentarz [The Public Finance Act. A Commentary], Warszawa: C.H. Beck, 2015.

Kucia-Guściora,B.: Art. 44 (in:) Smoleń, P. (ed.): Ustawa o finansach publicznych. Komentarz [The Public Finance Act. A Commentary], Warszawa: C.H. Beck, 2012.

Kostecki, M.J.: Efektywność organizacyjna. Przegląd koncepcji [Organisational Efficiency. A Review of Ideas], Organizacja i Kierowanie [Organisation and Management], No. 1-2 (1982).

Kostecki, M.J.: Socjologiczna koncepcja efektywności organizacyjnej [Sociological Approach to Organisational Efficiency], Problemy Organizacji [Problems of Organisation], No. 1 (1980).

Kowal, W.: Skuteczność i efektywność - zróżnicowane aspekty interpretacji [Effectiveness and Efficiency - Diverse Aspects of Interpretation], Przegląd Organizacji [Organisation Review], No. 4[157] (2013).

Lewin, A.Y. et al.: Determining Organizational Effectiveness: Another Look, and an Agenda for Research, Management Science vol. 32 no. 5 (1986).

Matwiejczuk, R. Efektywność - próba interpretacji [Efficiency - An Attempt at Interpreting], Przegląd Organizacji [Organisation Review], No. 11 (2000).

Mielich, A.: Efektywność gospodarowania. Istota-metody-warunki [Business Efficiency. Its Essence, Methods and Conditions], Warszawa: Państwowe Wydawnictwo Ekonomiczne [National Economic Press], 1980.

Mierzwa, A.: Art. 3 (in:) Smoleń, P. (ed.): Ustawa o finansach publicznych. Komentarz [The Public Finance Act. A Commentary], Warszawa: C.H. Beck, 2012. 
Mierzwa, A.: Art. 4 (in:) Smoleń, P. (ed.): Ustawa o finansach publicznych. Komentarz [The Public Finance Act. A Commentary], Warszawa: C.H. Beck, 2012.

Modzelewski, P.: System zarządzania jakością a skuteczność i efektywność administracji samorządowej [Quality Management System and the Effectiveness and Efficiency of Local Government Administration], Warszawa: CeDeWu, 2009.

Ostrowski, K.: Prawo finansowe. Zarys ogólny [An Outline of Financial Law], Warszawa: PWN [National Scientific Press], 1970.

Pszczołowski, T.: Mała encyklopedia prakseologii i teorii organizacji [Little Encyclopedia of Praxiology and Theory of Organisation], Wrocław: Ossolineum, 1978.

Pyszka, A.: Istota efektywności. Definicje i wymiary [The Essence of Efficiency. Definitions and Dimensions], Zeszyty Naukowe Uniwersytetu Ekonomicznego w Katowicach [Scientific Papers of the University of Economics in Katowice], No. 230 (2015).

Rutkowska, A.: Teoretyczne aspekty efektywności - pojęcie i metody pomiaru [Theoretical Aspects of Efficiency - the Notion and Methods of Measurement], Zarządzanie i finanse [Management and Finances], No. 1, part 4 (2013).

Skica, T.: Efektywność wydatkowania publicznego w Polsce [The Efficiency of Public Spending in Poland], Zeszyty Naukowe Wydziału Nauk Ekonomicznych [Scientific Papers of the Faculty of Economics], No. 14 (2010).

Skrzypek, E.: Efektywność ekonomiczna jako ważny czynnik sukcesu organizacji [Economic Efficiency as an Important Factor of Organisational Success], Prace Naukowe Uniwersytetu Ekonomicznego we Wrocławiu [Scientific Works of the University of Economics in Wrocław], No. 262 (2012).

Skrzypek, E.: Jakość i efektywność [Quality and Efficiency], Lublin: Wydawnictwo Uniwersytetu Marii Skłodowskiej-Curie [The Marie-Curie Skłodowska University Press], 2002.

Stigliz, J.E.: Ekonomia sektora publicznego [Economics of the Public Sector], Warszawa: Wydawnictwo Naukowe PWN [National Scientific Press], 2014.

Zieleniewski, J.: Organizacja i zarządzanie [Organisation and Management], Warszawa: Wydawnictwo Naukowe PWN [National Scientific Press], 1975.

Ziębicki, B.: Geneza modeli efektywności organizacyjnej, Organizacje Komercyjne i Niekomercyjne wobec Wzmożonej Konkurencji i Rosnących Wymagań Konsumentów [The Origins of Models of Organisational Efficiency. Commercial and Non-Commercial Organisations Faced by Increased Competition and Growing Consumer Requirements], vol. 7 (2008).

Zubik, M.: Dokonywanie mian w Konstytucji RP jako proces polityczny [Amending the Constitution of the Republic of Poland as a Political Process] (in:) Budziło, K. (ed.): Księga XXV-lecia Trybunału Konstytucyjnego [The Book to Commemorate the 25th Anniversary of the Constitutional Tribunal], Warszawa: Biuro Trybunału Konstytucyjnego [Office of the Constitutional Tribunal], 2010. 


\section{Legal Acts:}

The Constitution of the Republic of Poland of 2 April 1997 (Journal of Laws of 1997, No. 78 , item 483 , as amended).

The Fiscal Discipline Act of 17 December 2004 (consolidated text Journal of Laws of 2018, item 1458, as amended).

The Public Finance Act of 27 August 2009 (consolidated text Journal of Laws of 2017, item 2077, as amended). 